\title{
NOTE FROM THE MANAGING EDITORS
}

\section{The Prisoners' Pen at the Crossroads Mike Larsen and Justin Piché}

$\mathrm{T}$ his special issue of the Journal of Prisoners on Prisons (JPP) celebrates the PEN American Center's Prison Writing Program. Issue editor Bell Gale Chevigny - a dedicated, long-time advocate for and facilitator of prison writing - has compiled a collection of articles that includes past PEN American Center prize-winning narratives and new contributions solicited for this edition of the $J P P$.

Continuing with the themes discussed in Volume 18(1\&2), this issue again focuses on the experiences and socio-politics of incarceration in the United States as revealed through the written works of prison writers as well as the accounts of educators, facilitators, and documentary filmmakers who work to foster expression that transcends institutional barriers. This collection is intended to offer a glimpse into the largest penal system in the "free world", one the Conservative Administration in Canada seems intent on mimicking despite the overwhelming evidence that the "race to incarcerate" has had a negligible impact on 'crime', with fiscal and human costs that have shown to not be worth the price of purchase (see Mauer, 1999; Mauer and Chesney-Lind, 2002).

As Susan Nagelsen, Associate Editor of the JPP, notes in her Response, this issue represents a welcome collaboration between groups that share a mandate for fostering and providing a vehicle for writing as resistance. The importance of prison writing and an appreciation for the venues that make it possible have been subjects of discussion and analysis in these pages since the inception of the $J P P$, and this issue joins a number of previous editions that have made writing, expression, and the penal press their focus. ${ }^{1}$

While this volume focuses on the United States, the articles speak to "carceral universals" (Gaucher, 2008, p. 2) that transcend history and geography. Prisoners the world over will hear echoes of their own experiences in Michael Rothwell's discussion of suicide and self-harm, and William Steed Kelley's account of endemic violence. Christopher J. Best's contribution is in many ways particular to the context of Texas Death Row, but his effort to make sense of institutionalized murder resonates with the literature on prisons as spaces epitomizing the biopolitics of disposability (see Bauman 2004; Byrd 1995; Giroux 2009). And anyone, anywhere, 
who has ever attempted to work with, survive, or resist the penal system will identify with Patrica Prewitt's excellent account of the contradictory and Kafkaesque prison bureaucracy. This bureaucracy serves to discipline and micro-regulate life on the inside, while simultaneously managing or prohibiting 'outsider' access to the prison. As noted by filmmaker Susanne Mason (this issue, p. 84), "the walls work both ways".

Thankfully, efforts to transcend and overcome the walls also work both ways, and the written word is a powerful vehicle for this. Prison writing is often a lifeline - a means to resist the dehumanizing and totalizing experience of incarceration through expression and creativity. As Bell Chevigny (1999, p. xxiv) observes in her anthology Doing Time, "many prisoners write as if their lives depend on it. Quite often they do". Writing is also a means to counter-inscribe the prison-industrial complex by deconstructing its core narratives and advancing alternative discourses borne of experience (Gaucher, 2002, p. 21). Further, we would argue that the writings of prisoners on prisons contribute to an evolving institutional memory that links persons, places and policies. In other words, it is possible to read the folly of next year's carceral expansion agenda in the decade-old account of a prisoner who has lived through a similar experience.

We, in Canada and in the United States, find ourselves at a crossroads. Faced with the reality that the construction and operation of carceral institutions diverts important funds from vital services such as education and health care, particularly in a time of economic crisis, many American States are considering measures to sharply reduce their reliance on imprisonment as a panacea to social problems. At the same time, the Canadian federal government is conducting a needs assessment to decide whether or not to construct new penitentiaries for men at a rate not seen since the 1960s, 1970s and 1980s (see Jackson and Stewart, 2009). At this stage of the carceral game, one where lives and futures are at stake, the JPP seeks to contribute to this debate through the prisoners' pen.

We were excited when Bell approached us with the idea for this issue, and we hope that you will find it as engaging as we do.

\section{ENDNOTES}

1 See, for example, Bob Gaucher's Response in the first issue of the $J P P$, "The Prisoner as Ethnographer", as well as JPP Volume 2(1) (1989), on "The Penal Press and 
Selected Articles", Volume 10(1\&2) on "Prison Writing and Prison Writers", and the JPP Anthology "Writing as Resistance" (2002). Prison writing is, of course, a core underlying theme in every issue of the $J P P$, and an issue at the heart of our mandate as a journal.

\section{REFERENCES}

Bauman, Zygmunt (2004) Wasted Lives: Modernity and its Outcasts, Cambridge: Polity.

Byrd, Johnny 'ByrdDog' (1995) “The Last Mile”, Journal of Prisoners on Prisons, 6(1): 70-74.

Chevigny, Bell (ed.) (1999) Doing Time: 25 Years of Prison Writing - A PEN American Center Prize Anthology, New York: Arcade Publishing, Inc.

Gaucher, Bob (2008) "Carceral Universals", Journal of Prisoners on Prisons, 16(2): $1-7$.

Gaucher, Bob (ed.) (2002) Writing As Resistance: The Journal of Prisoners on Prisons Anthology (1988-2002), Toronto: Canadian Scholars Press Inc.

Giroux, Henry A. (2009) Youth in a Suspect Society: Democracy or Disposability?, New York: Palgrave Macmillan.

Jackson, Michael and Graham Stewart (2009) A Flawed Compass: A Human Rights Analysis of the Roadmap to Strengthening Public Safety,

http://www.justicebehindthewalls.net/resources/news/flawed_Compass.pdf.

Mauer, Marc (1999) Race to Incarcerate, New York: The New Press.

Mauer, Marc and Meda Chesney-Lind (eds.) (2002) Invisible Punishment: The Collateral Consequences of Mass Imprisonment, New York: The New Press. 